\title{
Lessons Learned from the Water Producer Project in the Atlantic Forest, Brazil
}

\author{
Ricardo A. G. Viani ${ }^{1, *(\mathbb{D}}$, Henrique Bracale ${ }^{2}$ and Denise Taffarello ${ }^{3}$ \\ 1 Department of Biotechnology and Plant and Animal Production, Federal University of São Carlos (UFSCar), \\ Araras-SP 13600-970, Brazil \\ 2 The Nature Conservancy, São Paulo-SP 01311-936, Brazil; hbracale@tnc.org \\ 3 Department of Hydraulics and Sanitation (SHS, EESC), University of São Paulo (USP), \\ São Carlos-SP 13566-590, Brazil; taffarellod@gmail.com \\ * Correspondence: viani@ufscar.br
}

Received: 13 September 2019; Accepted: 13 November 2019; Published: 15 November 2019

check for updates

\begin{abstract}
Forest and landscape restoration (FLR) is a powerful strategy for large-scale tropical forest recovery, and payment for ecosystem services (PES) is used to support FLR programs and projects on privately-owned land. In this article, we discuss the lessons learned from the Water Producer Project, a pioneer, multiple-stakeholder, and PES-supported FLR project in the Atlantic Forest, south-eastern Brazil. The project was implemented in four landscapes located in two municipalities. Altogether, 41 PES contracts with landowners were signed, resulting in various FLR practices being implemented in a total of 342.4 ha (64.2 ha for riparian forest restoration, 90.8 ha for soil conservation, and 187.4 for forest conservation) of land, which represents 39\% of the project goal. As of the end of the project, only 50\% (USD 49,250) of the available PES funds had been spent. However, funds spent on project planning, implementation, communication, and monitoring were 12 times greater than those spent on PES. Several challenges restricted the progress and monitoring of the project. The main issue was landowner participation and/or engagement. In terms of lessons learned, we highlight that PES schemes are more complex than initially thought, and that sufficient funding does not guarantee the success of FLR projects. It is essential to promote landowner participation and engagement by considering them key players in FLR projects. Finally, acceptance from landowners was higher and implementation was easier for forest conservation practices that required no land-use changes. Thus, we suggest that similar future projects should focus on targeting private properties in marginal agricultural lands with a high probability of natural regeneration. Alternatively, future projects could focus on lands with remnant forest cover of high conservation value.
\end{abstract}

Keywords: ecological restoration; landowner engagement; forest and landscape restoration; forest restoration; payment for ecosystem services; tropical forest; water

\section{Introduction}

Forest and landscape restoration (FLR) is a balanced, large-scale approach that goes beyond the goal of ecosystem restoration. While ecosystem restoration is the process of assisting the recovery of an ecosystem that has been degraded, damaged, or destroyed [1], FLR is a planned process that aims to regain ecological integrity and enhance human well-being in deforested or degraded landscapes [2]. Forest and landscape restoration is a powerful strategy for large-scale restoration, and is widely advocated for in the agendas of global, national, and regional institutions working in tropical forests [3].

Payment for ecosystem services (PES) can support FLR programs and projects situated on privately-owned land [4,5]. These schemes can increase landowner participation and improve landowner livelihoods through putting a monetary value on the beneficial effects of FLR practices on 
the provision of ecosystem services. Both PES programs and FLR projects are expanding in the tropics, with successful and unsuccessful forest restoration results being reported at the landscape level [6-8].

South America plays a major role in global tropical forest conservation and restoration $[9,10]$. Brazil, for instance, has established an ambitious national target of restoring 12 million hectares of native vegetation by 2030 (Federal Decree No. 8972, 2017). The Atlantic Forest Restoration Pact (PACTO) is as a collective, multi-sectorial effort to restore 15 million hectares of the threatened Atlantic Forest biome [11], which is a global hotspot for biodiversity conservation [12] with less than $16 \%$ of its original cover remaining [13]. PES schemes are also growing in prevalence Brazil, especially in the Atlantic Forest [14]; the most degraded and most populous region in the country. Many PES projects are being established through partnerships between local institutions and the national Water Producer Program, created in the early 2000s by the National Water Agency with the goal of providing financial incentives to rural landowners who adopt water and soil conservation practices [15].

The national Water Producer Program is based on the Brazilian National Policy on Water Resources (Federal Law n. 9433/97). Currently, almost 20 years after its creation, the program has implemented approximately 40 projects throughout Brazil, most of which are in the south-east [16]. These projects are now increasing in relevance because of recurrent and recent water crises in Brazil. In 2013 and 2014, an extreme drought resulted in a severe water crisis in the state of São Paulo $[17,18]$. Thus, examining the challenges faced by and the lessons learned from water-related PES schemes has become urgent and extremely relevant, given that they may be applicable to related water challenges such as climate change and drinking water supply.

In this paper, we examine the Water Producer Project in the Piracicaba-Capivari-Jundiai Watershed ("Produtor de Água no PCJ", hereafter Water Producer/PCJ): a pioneer and local FLR project developed in partnership with the national Water Producer Program implemented in two municipalities within the Brazilian Atlantic Forest. The project took place from 2008 to 2015, and tested a PES scheme as a strategy for implementing FLR practices and improving water-related ecosystem services at the landscape level. Given the increasing interest in PES schemes and their effects on FLR implementation, our objective was to describe the challenges faced by, and consequently the lessons learned from, this pioneer case study. In addition, we discuss the possible implications of the lessons learned on future FLR projects aiming to use PES schemes as tools for improving landowner participation and FLR implementation in the tropics.

Following a logical order, we describe the project's background (sites, goals, implementation, monitoring, and outcomes) in Sections 2-4. Then, in the subsequent sections, we discuss the main challenges faced by and the lessons learned from Water Producer/PCJ. Challenges and lessons learned were listed primarily considering our own synthesis as managers directly involved in project planning, implementation, and monitoring. Additionally, we consulted (1) the informal testimonies of landowners, project partners, and technicians (e.g., Appendix A), and (2) project results described in documents and papers [14,19-24].

\section{Project Site, Structure, and Support}

Water Producer/PCJ was developed in the municipalities of Joanópolis $\left(22^{\circ} 54.5^{\prime} \mathrm{S}\right.$ and $\left.46^{\circ} 10.6^{\prime} \mathrm{W}\right)$ and Nazaré Paulista $\left(23^{\circ} 13.9^{\prime} \mathrm{S}\right.$ and $\left.46^{\circ} 19.5^{\prime} \mathrm{S}\right)$, both located in the state of São Paulo, south-eastern Brazil. These municipalities include the Piracicaba, Capivari, and Jundiai (PCJ) watershed, which feeds into the Cantareira water supply system (Figure 1). The Cantareira water supply system is a set of five reservoirs that provides water for almost 15 million people in the São Paulo and Campinas metropolitan regions $[17,25]$. Because of its importance as a water source, this region is the target of many forest restoration programs aiming to improve water-related ecosystem services and water security $[20,26,27]$.

In 2007, at the beginning of the project, one landscape was selected per municipality. The project began with the Cancan (Joanópolis 1141 ha, 55 properties) and Moinho (Nazaré Paulista, 1757 ha, 70 properties) sites, totaling 2898 ha and 125 properties. Because of low landowner participation, 
the area of the project was expanded during its early years, incorporating the Cachoeiras dos Pretos (Joanópolis, 13,040 ha) and Cuiabá (Nazaré Paulista, 3825 ha) sites. Thus, the overall project involved four landscapes in two municipalities, totaling 18,006 ha (Figure 1). These four areas were chosen for the project because of the availability of biophysical data and satellite images, which also led to prior government-funded projects in these areas. Due to the fact that a major goal of the project was to increase provisioning of water-related ecosystem services, landscapes were delimited according to the limits of the watershed. However, for the Cancan site in Joanópolis, only part of the watershed was included in the project because the upper part of the watershed is located outside of the state of São Paulo (Figure 1).

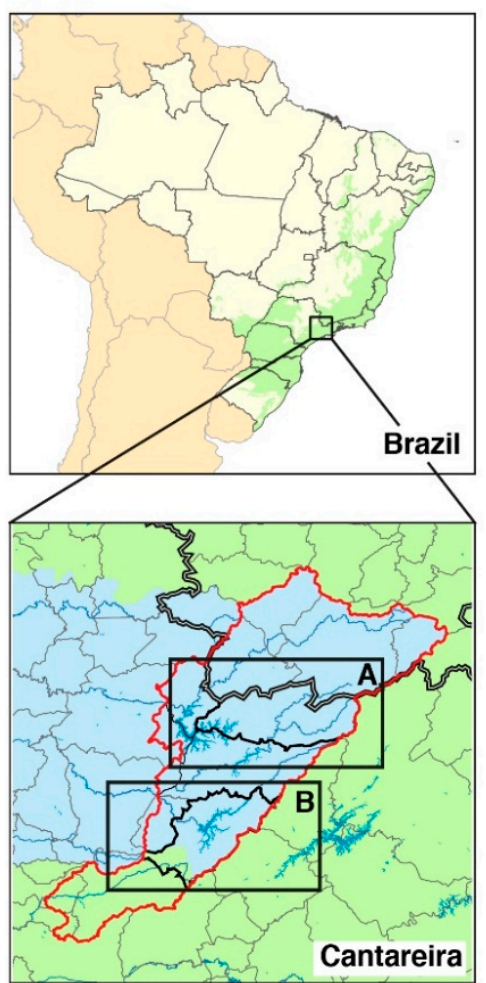

Reservoir $=$ State boundary - Main river - Municipality boundary
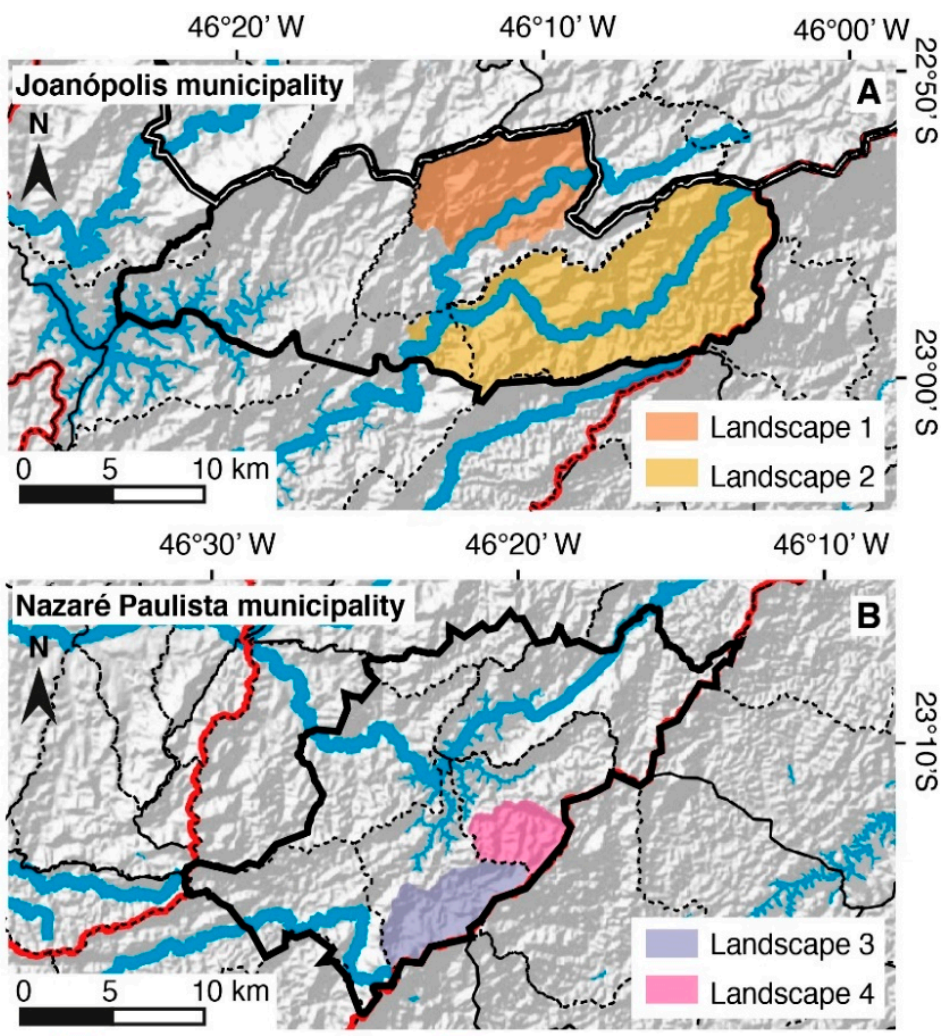

$\square$ Cantareira water system

PCJ watershed

Atlantic forest - original distribution

Figure 1. Landscapes involved in the Water Producer Project, located in the Piracicaba, Capivari, and Jundiai watershed, Atlantic Forest, Brazil.

All four landscapes are dominated by privately-owned small farms with low-intensity and low-productive pastures. Complementary to pastures, there are Eucalyptus plantings, many small recreational properties, and, at Joanópolis, crop plants such as potato and cherry tomato. A low level of technology is a feature of most of the productive systems found in both municipalities. The regional native vegetation is highly-diverse seasonal semideciduous forest, which occurs under a seasonal climate, with rainfall concentrated in the summer (October-March) and a dry season in the winter (April-September). Deforestation began centuries ago in both municipalities, and was driven by diverse agricultural cycles. However, deforestation has almost ceased in recent decades, and all forest remnants are protected by Brazilian Law n. 11,428 on the use and protection of the Atlantic Forest [28]. Currently, the native forests found in the landscapes are mostly secondary and degraded, and generally demand restoration actions [13,29]. The native forest remaining at Joanópolis and Nazaré Paulista are $11.9 \%$ and $20.9 \%$, respectively [28], and this remaining forest is concentrated in marginal agricultural areas. Riparian areas in the landscapes have also been subjected to degradation, with forest buffers missing along many watercourses (Figure 2A). 


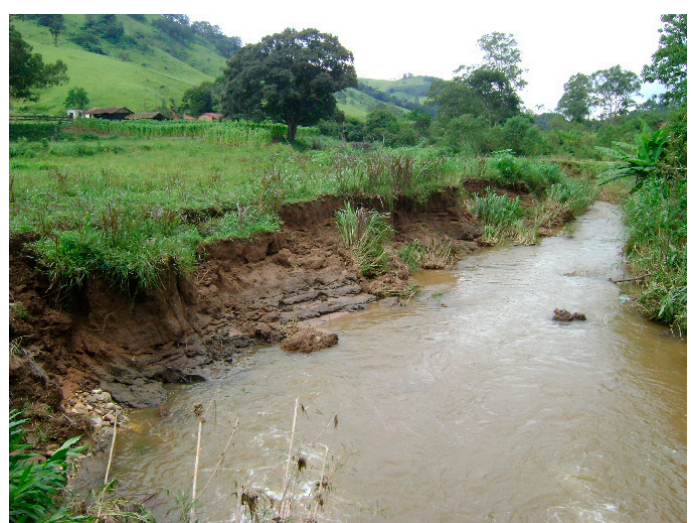

(A)

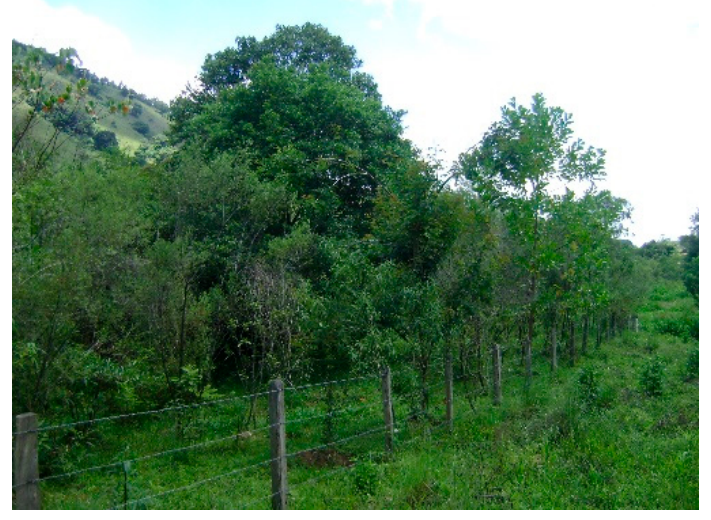

(B)

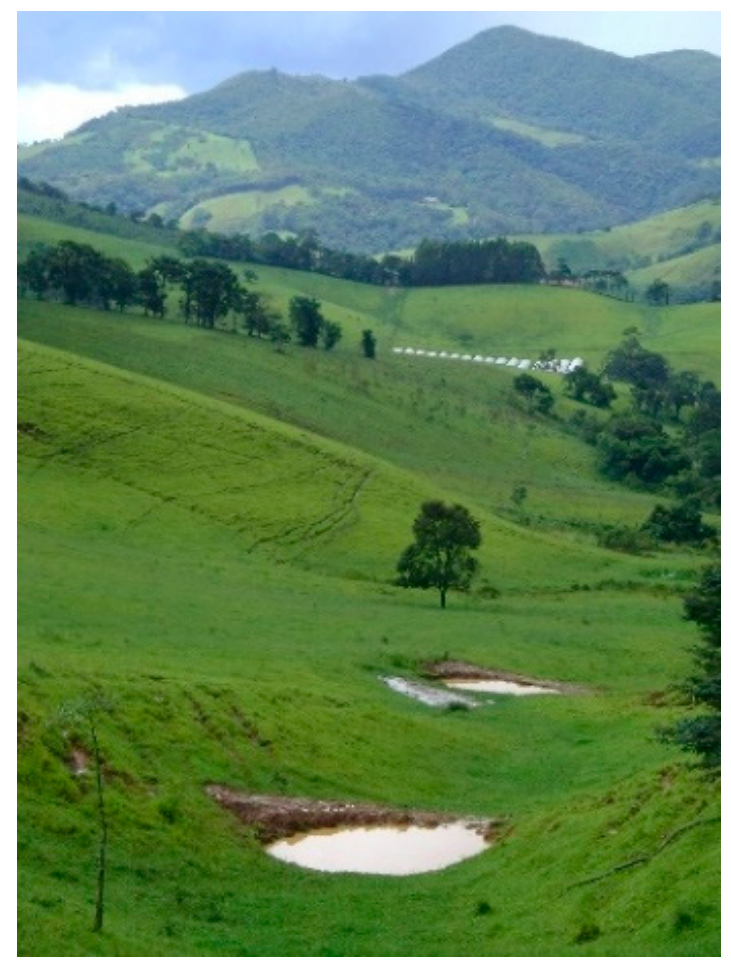

(C)

Figure 2. Images from the Water Producer Project, in the Piracicaba, Capivari, and Jundiai watershed, Atlantic Forest, Brazil: (A) degraded riparian area; (B) native tree seedlings planted for forest restoration; (C) infiltration holes to reduce rainwater runoff.

Discussions to create this project began in 2006 (Figure 3) through a formalized alliance of The Nature Conservancy Brazil, the São Paulo State Environmental Secretariat, the São Paulo State Agriculture and Supply Secretariat, and the Brazilian National Water Agency (ANA). The PCJ Watershed Committee implemented a water use charge in 2007 (PCJ Joint Deliberation 048/2006). According to Brazilian water resource national police (Federal Law n. 9433 from 1997), watershed committees may implement water use charges, and the funding provided by these charges may be used to improve green infrastructure within the watershed. Thus, the PCJ Watershed Committee was involved in the discussion, which resulted in the creation of a PES scheme to support the project with the PES funds coming from water use charges. The Nature Conservancy managed these funds and executed the payments to landowners. As the project progressed, additional institutions became partners, each one with a specific role, transforming this into a multiple-stakeholder project with governmental and non-governmental institutions participating (Appendix B). Project partners created a "management team" with representative members from all project partners. This management team 
met periodically to approve or reject implementation projects on individual properties and to discuss project progress, challenges, and changes needed. There was no direct participation of landowners in the management team.

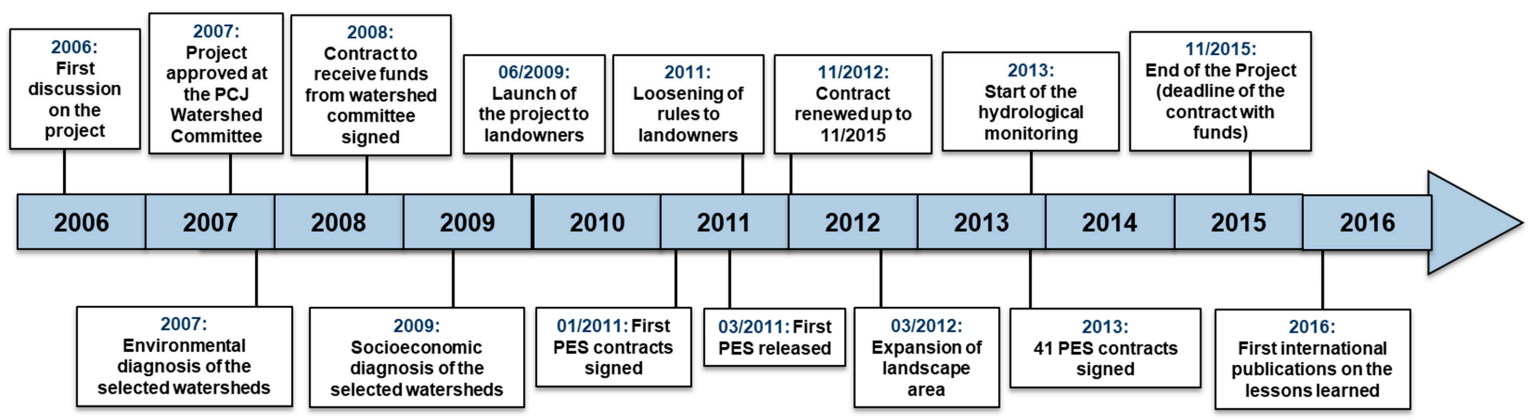

Figure 3. Timeline of the Water Producer Project, in the Piracicaba, Capivari, and Jundiai watershed, Atlantic Forest, Brazil. Modified from [24] (p. 17).

The objective of the project was to test the efficiency of PES to landowners as a strategy for the implementation of FLR practices in a priority region for provisioning water-related ecosystem services. In addition, the project aimed to implement FLR practices on 1258 ha of land, comprising: forest conservation on 540 ha, forest restoration in riparian areas under permanent protection (areas protected by Federal Law in Brazil—see [30] for details) on 208 ha, and soil conservation practices on 510 ha. These practices were expected to have positive impacts on water quality and on the regularity of water supply in the landscapes. While PES funds came from the PCJ Watershed Committee, the other partner institutions funded the implementation and monitoring of the FLR practices, in addition to project communication and monitoring.

PES payments to landowners were initially defined based on the opportunity costs of low-intensity cattle ranching, which is the dominant productive system in both municipalities. However, PES payments to landowners varied from USD 6.25 to 31.25 per hectare per year (Table 1). Variation was added according to the categories of eligible activities (i.e., forest conservation, forest restoration, and soil conservation) to foster both landowner participation and the provision of water-related ecosystem services. Within forest conservation, PES values increased with the percentage of riparian permanently protected area that was conserved or delivered for restoration within the property (the minimum requirement was $15 \%$ ), and was higher for medium or advanced than for early successional forests (Table 1, Appendix C). For soil conservation, higher PES values were established for greater soil erosion abatement (Table 1, Appendix C). Payment for ecosystem services payments dispensed during the project totaled USD 98,812, comprising USD 50,625 for forest conservation, USD 19,500 for forest restoration of riparian areas under permanent protection, and USD 28,687 for soil conservation practices.

Table 1. Values assigned for payment for ecosystem services payments to landowners for forest and landscape restoration practices in the Water Producer Project in the Piracicaba, Capivari, and Jundiai watershed, Atlantic Forest, Brazil. Variation within forest conservation was related to the percentage of riparian permanently protected area that was forested or was delivered for restoration in the property, while for soil conservation the variation was based on soil erosion abatement (\%) provided by the adopted practice. 1 USD = BRL 4 (November, 2019).

\begin{tabular}{|c|c|}
\hline FLR Practice & $\begin{array}{l}\text { Payment for Ecosystem Service Value } \\
\text { (USD. ha }{ }^{-1} . \text { Year }^{-1} \text { ) }\end{array}$ \\
\hline $\begin{array}{l}\text { Forest restoration in areas under permanent } \\
\text { protection (APP) }\end{array}$ & 31.25 \\
\hline Forest conservation: early successional forest & $6.25-18.75$ \\
\hline $\begin{array}{l}\text { Forest conservation: medium to advanced } \\
\text { successional forest }\end{array}$ & $10.5-31.25$ \\
\hline Soil conservation & $6.25-18.75$ \\
\hline
\end{tabular}




\section{Project Implementation and Monitoring}

Prior to the start of the project, the landscapes were subjected to environmental and socioeconomic studies (Figure 3). The environmental study focused on mapping the following: (1) current land-use, (2) the limits of properties and, (3) areas that should be legally protected or restored according to the Brazilian Forest Code (Federal Law n. 4771 from 1965, which lasted until 2012). The socioeconomic study consisted of interviews with landowners to collect data on socioeconomic indicators, as well as to understand landowners' perceptions on environmental issues, expectations of FLR projects, and awareness of PES and its related factors. The socioeconomic survey indicated that overall $42 \%$ of landowners were (and 22-34\% could be) interested in participating in a new project proposing changes to their agricultural land-use [31]. Third-party institutions, hired by project partners, conducted the environmental and socioeconomic studies.

Project implementation followed a sequence of steps from the identification of an interested landowner to the release of the PES payments (Figure 4). There was a set of criteria for landowner eligibility for the project and for practice implementation. These criteria were launched in 2009 (Figure 3) as part of a guideline reference document for participation in the project. This reference document was expanded upon by project partners and was revised, simplified, and relaunched in 2011. The 2011 version was created with the aim of softening the participation criteria in order to increase landowner participation, which was low at that time and was a barrier to the progress of the project. To be eligible, landowners had to provide a set of personal documents and prove land tenure or ownership. While this guaranteed that the public funds from the PCJ Watershed Committee were really being delivered to the owners of the lands, it prevented some interested landowners from participating in the project.

Once landowners had expressed an interest in participating in the project, project technicians created a preliminary project unique to each property which included all FLR practices within the project scope that were recommended for the property. This was called the "ideal" project. Then, this ideal project was presented to the landowner, who was then able to decide which aspects and practices he or she would like to implement, respecting two rules: (1) at least $15 \%$ of the permanently protected riparian areas within the property were protected or delivered for forest restoration; and (2) at least $25 \%$ of the proposed FLR practices had to be accepted. Once both parties agreed to the project scope and the locations for FLR practices to be implemented, the project was redesigned and converted into an implementation project. Then, personal and land tenure documents from the landowners were provided and a three-year PES contract was signed between landowners and The Nature Conservancy, the leading institution which legally received the PES funds from the PCJ Watershed Committee. After the PES contracts were signed, FLR practices were implemented. Forest conservation, restoration, and soil conservation practices were executed and funded entirely by project partners, except in cases where landowners were interested in implementing specific soil conservation practices that were not originally included in the list of practices funded by the project. This was rare and, in the majority of cases, landowners received both PES and full FLR practice execution.

In general, the funded forest conservation practices consisted of fence-making and enrichment planting with native trees, while for forest restoration, funded practices included assisting natural regeneration and planting native tree seedlings in riparian areas (Figure 2B). Even though forest fragments in the four landscapes were protected against deforestation by law, they were all eligible for forest conservation practices because they were generally already degraded or under degradation, therefore demanding restorative actions. For soil conservation, funded practices were designed to reduce soil erosion, such as construction of terraces and rainwater infiltration holes (Figure 2C), and implementation of no-till farming and tree planting. All practices were designated as eligible for PES because of the positive impact they were expected to have on water-related ecosystem services, and because improving the provision of water-related ecosystem services was the main goal of the project.

After FLR practices had commenced, technicians (project partners and Watershed Committee members) visited the areas being worked on every six months to confirm that they were being protected 
or that practices were still being adopted. Once practices were approved after monitoring, PES were released to landowners (six payments, twice a year).

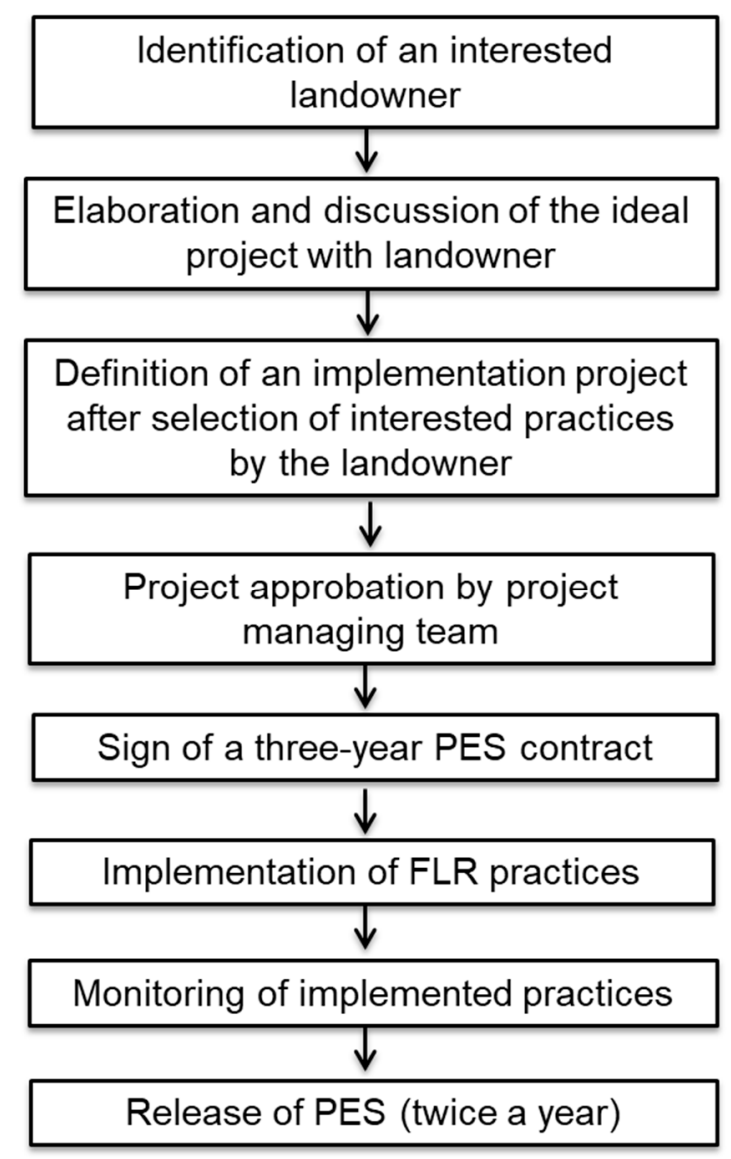

Figure 4. Sequence of actions for the implementation of forest and landscape restoration practices in the Water Producer project, Piracicaba, Capivari, and Jundiai Watershed, Atlantic Forest, Brazil. Modified from [24] (p. 41).

No baseline monitoring was carried out to evaluate the real benefits of the implemented FLR practices in terms of improvements to water-related ecosystem services. Although project partners extensively discussed hydrological monitoring during project planning, monitoring was only implemented in 2013 in the Joanópolis municipality and in 2014 in the Nazaré Paulista municipality (Figure 2). Hydrological monitoring was designed to evaluate qualitative and quantitative water indicators at the watershed's outlets, and to periodically collect water flow data in conserved micro-watersheds (forest cover $>80 \%$ ) and in properties participating in the project. No monitoring or surveying of landowners was done after the start or end of the project to measure landowner perceptions or socioeconomic changes or to gain their opinions on the project.

\section{Project Outcomes}

The first pilot commenced in 2010, and the first PES was released in 2011, three years after the formal start of the project. In 2011, 2012, and 2013, 7, 20, and 14 PES contracts, respectively, were signed. This resulted in 41 PES contracts (Table 2) and the participation of 38 landowners (28 men, nine women, and a company) in total.

At the end of the project (2015), only 50\% (USD 49,250) of the funds initially available for PES had been spent. In a survey with project partners, we estimated that around USD 600,000 was spent by project partners on project planning, implementation, communication, and monitoring, which represent a ratio of PES costs to other project costs of 1:12. Thus, while this shows that project partners 
were able to raise funds for practical implementation based on the funds available for PES, it also demonstrates that PES-specific funds are just a small fraction of the total cost of a PES project such as this.

Table 2. Number of properties $(\mathrm{N})$ and areas of implementation for the FLR practices involved in the Water Producer Project in the Joanópolis and Nazaré Paulista municipalities, Piracicaba, Capivari, and Jundiai Watershed, Atlantic Forest, Brazil.

\begin{tabular}{ccccccc}
\hline \multirow{2}{*}{ Practice Type } & \multicolumn{2}{c}{ Joanópolis } & \multicolumn{2}{c}{ Nazaré Paulista } & \multicolumn{2}{c}{ Total } \\
\cline { 2 - 7 } & $\mathbf{N}$ & Area (ha) & $\mathbf{N}$ & Area (ha) & $\mathbf{N}$ & Area (ha) \\
\hline Forest restoration in areas under & 23 & 64.2 & 5 & 4 & 28 & 68.1 \\
permanent protection (APP) & 28 & 187.4 & 11 & 134 & 39 & 321.4 \\
$\quad \begin{array}{c}\text { Forest conservation } \\
\text { Soil conservation practices }\end{array}$ & 17 & 90.8 & 3 & 8.5 & 20 & 99.3 \\
Total & 29 & 342.4 & 12 & 146.5 & 41 & 488.9 \\
\hline
\end{tabular}

Altogether, 489 ha of land were subjected to interventions by the project, which represents $39 \%$ of the original goal and $2.7 \%$ of the combined area of the four landscapes. The original target area was not achieved for any category of practice (i.e., forest conservation, forest restoration, or soil conservation) eligible for PES (Figure 5). The number of PES contracts and the total area worked on by the project were higher for forest conservation than for soil conservation and forest restoration, and this was reflected in the fact that achievements were closer to the original goal for forest conservation than for the other practices. Joanópolis had more than double the number of PES contracts and an area of implementation that was almost twice as large as that of Nazaré Paulista.

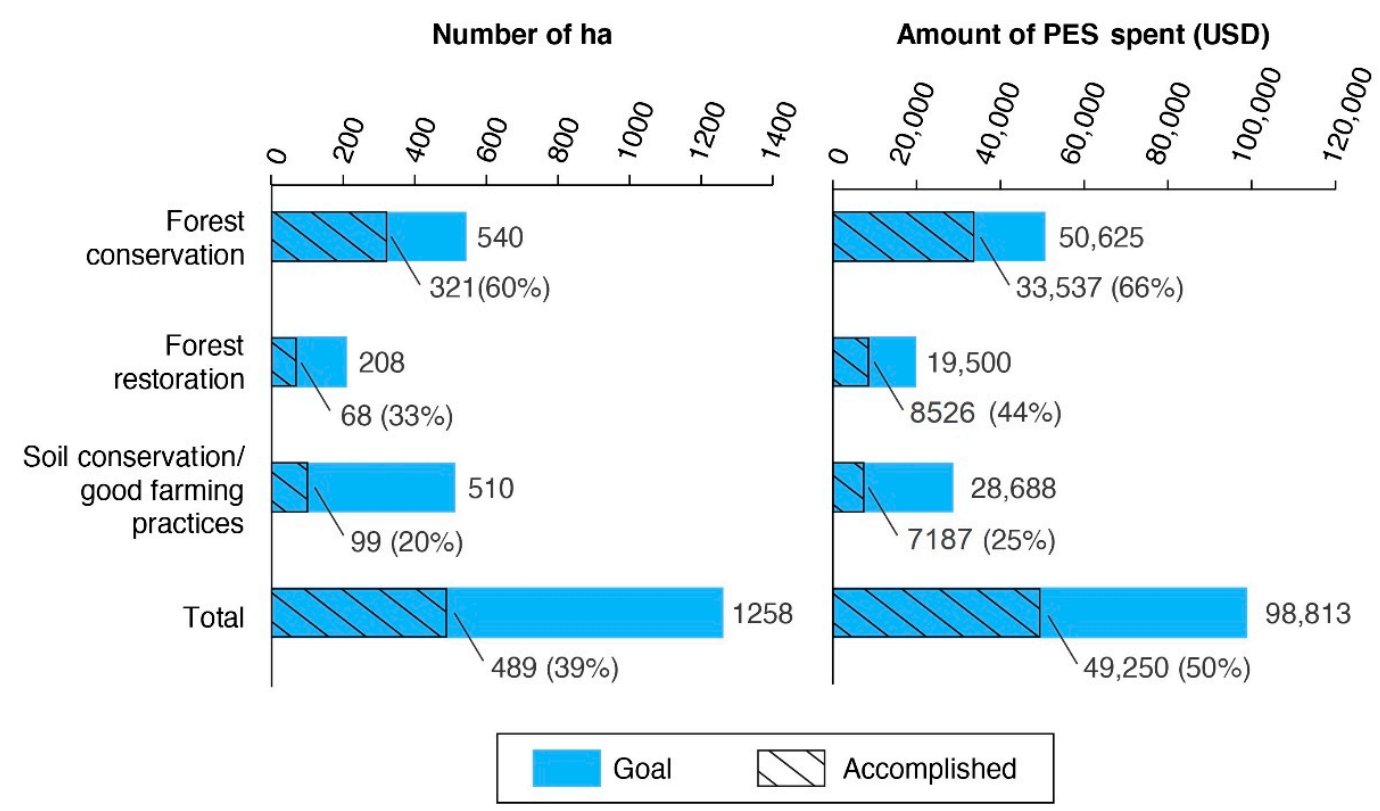

Figure 5. Achievements compared to the goals of the Water Producer Project, Piracicaba, Capivari, and Jundiai Watershed, Atlantic Forest, Brazil, in terms of implementation area (number of hectares) and PES funds spent. Percentages are achievements in relation to the original goal.

If forest conservation (no land-use change) is excluded, the project promoted land-use change on 167.4 ha $(0.93 \%$ of the whole area) of land. This land-use change had a definite local impact on each worked property and its landowners. However, overall, this result demonstrates that the percentage of the landscapes that underwent land-use change was small. In addition, forest restoration was implemented on just 68.1 ha, which represents $0.38 \%$ of the whole area of the landscapes, and is a small 
percentage in terms of landscapes changes. Biological integrity was not a project goal. However, even if all forest restoration areas are considered to be successfully restored (an optimistic approach), this would clearly not increase forest cover to $33 \%$, which is the minimum amount of cover for biological integrity at the landscape level [32]. Thus, at this rate of reforestation, it would probably take centuries to reach the forest cover threshold for forest functioning in the studied landscapes [20], and even this would likely be insufficient to increase forest connectivity, contrary to the results of other PES projects in the Brazilian Atlantic Forest [27].

We considered that the project was successful at testing a PES scheme as a strategy for FLR implementation. This project was the first to be implemented in the state of São Paulo that trialed PES to rural landowners as a strategy for natural resource conservation and livelihood improvement. Additionally, this was the first project to access water use charges from a watershed committee to fund a PES scheme, and consequently, FLR implementation in Brazil. Despite the challenges faced, we believe that this project has played an important role in paving the way for the use of Water Funds to finance FLR in Brazil [8].

Several lessons were learned from Water Producer/PCJ that are currently informing the planning and implementation of PES projects and policies in the state of São Paulo and in the Atlantic Forest. For example, the state of São Paulo established its Climate Change Police in 2009 (State Law n. 13.798), which included lessons from the first years of Water Producer/PCJ to define strategies for PES. However, the amount of money available for PES was not all spent during the project, and the number of hectares subjected to FLR practices was below the initially established goal. In addition, no data was collected to confirm whether the implemented practices actually improved water supplies and other related ecosystem services at the landscape level.

\section{Challenges}

Regarding implementation area, the project was partially successful because only part of the initial target was achieved, and had to deal with many challenges that affected its progress, success, and sustainability over time. Here, we divide the aforementioned challenges into three categories and discuss how these challenges affected the project and, if applicable, we mention how these challenges were addressed and the results of these actions. In many cases, the challenges were related to each other. Then, in the following section, we discuss how these main challenges became lessons learned, and how they are useful for those aiming to design and implement similar projects across tropical regions.

\subsection{Social Challenges Impacting Landowner Participation and/or Engagement}

1. Mistrust in a new project after a sequence of unsuccessful projects: It is hugely challenging to change negative perceptions created from a history of unsatisfactory participation in funded projects [24]. Landscapes were selected for participation in the project based on the fact that government-funded initiatives had previously been attempted there. While this was efficient-because a significant amount of data on the landscapes was available for project planning - this selection also created a challenge because some of these previous projects did not meet landowners' expectations. In addition, many landowners recognized that some Water Producer/PCJ partners had participated in these previous initiatives, decreasing their trust in the project. We also noticed that, across the four landscapes, mistrust was sometimes related not to unsatisfactory participation in a specific project, but to the wariness that some landowners had towards the technical abilities and general capabilities of NGOs and official government bodies. Finally, landowner wariness towards participation also arose due to the novelty of PES schemes [6,24]. Landowners in all landscapes had not previously participated in PES projects. Thus, the idea of receiving funds for conservation practices implemented on their land initially stimulated suspicion regarding whether it was true or possible. To deal with these challenges, project partners communicated and met with landowners frequently to explain project details. While this was effective at convincing landowners that payments would be made for implemented 
conservation practices, most landowners were hesitant to participate until the first participants had received their PES payments.

2. Short duration and uncertainty of renewal of PES contracts: PES contracts only lasted for three years, and uncertainty over contract renewal posed a great challenge in terms of landowner participation. Short duration of PES contracts was a particular challenge when FLR practices required landowners to change from a productive land-use to forest restoration. In these cases, landowners argued they would move from a free-chosen productive and profitable system to a permanent system (forest restoration) which would generate income for them for just three years. This was one of the reasons why fewer landowners accepted forest restoration practices compared to other practices. Restrictions in the availability of funds limited the establishment of long-term PES contracts. Furthermore, as mentioned previously, PES payments are just one small component of the overall cost of projects like this, as the sustainability of FLR projects depends on funds for project communication, monitoring, and FLR practice implementation. In fact, regular funding and, consequently, long-term sustainability have previously been cited as challenges for FLR implementation [24,26].

3. Low value of PES payments: PES payments were defined based on opportunity costs (Table 1), which is common practice in PES scheme implementation [6]. Opportunity costs were based on low-technology pastures, which was the most common land-use in all of the project's landscapes. However, other more profitable land-uses existing in the landscapes, such as the Eucalyptus plantations that were expanding in the four landscapes at the time of project implementation, were ignored in this process [24]. Since there was no option to change the PES values (see the next challenge below), the low PES value became a challenge for landowner participation. Furthermore, initial budgeting of PES payments did not take Brazilian inflation rates into account, and an annual correction of 7\% in PES values was only implemented after 2013. Since annual inflation rates varied from $5.9 \%$ to $10.7 \%$ [33] during the project (2008 to 2015), this significantly reduced the positive impacts of the PES payments over time and, consequently, decreased the attractiveness of these payments to landowners.

4. Restrictions in the use and flexibility of funds available for the project: Water Producer/PCJ was funded by water use charges from the PCJ Watershed Committee, as an application of the users-pay principle, which was a pioneering and promissory strategy for funding PES projects at the time [22]. However, the way that this was operationalized proved to be inefficient for the project and for PES projects in general. Funds had to be received and managed by a third party (i.e., funds did not go directly to landowners from the Watershed Committee), via a contract signed between this third party and a Brazilian federal bank that outlined specific financing rules for this contract. Once this contract was signed, resources could not be reallocated among funded FLR practices, and PES values, contract duration, and project budget disbursement could not change over time. Payment for ecosystem services was a novel approach for the region at the time, and there was significant unpredictability in landowner participation and in the choice of FLR practices. Thus, this lack of flexibility in the use of the PES funds was a barrier to addressing the challenges identified as limitations at the beginning of the project, such as low PES values and short duration of PES contracts. Consequently, this lack of flexibility directly contributed to reduced landowner participation. We also identified biannual payments to landowners as a limitation, as landowners argued for the monthly payments that were being used in the neighboring "Conservador das Águas" project, located at Extrema-MG $[19,26]$. Project partners also agreed that monthly payments could increase engagement. However, since there were restrictions in place to prevent changes such as this, and the fact that monthly payments would be more laborious to operationalize, payments were kept to twice a year. In short, this highlights an important limitation of the project: These restrictions meant that adaptive management could not be applied to improve program effectiveness. Positive examples overcoming this limitation 
have been practical field investigations with different contractual types that have been performed in the USA and Germany [34].

5. No direct implementation at any level by landowners: Implementation of FLR practices was funded and implemented entirely by project partners. On the one hand, this approach was necessary, because it enabled landowners that could not afford to implement conservation practices to join the project. Active forest restoration by planting native tree seedlings, for example, is an expensive practice with costs of more than USD 5000 per hectare in low-resilience Atlantic Forest patches [35]. Most landowners would not implement these practices without the financial support of project partners. On the other hand, since landowners were not directly involved in any of the FLR practices, they were not closely engaged in the project. This risked the quality of the implemented practices, because landowners were not necessarily engaged enough to take care of them on their own properties. Further, direct landowner engagement increases the feeling of ownership, which is essential for the long-term sustainability of FLR projects [10,36]. Therefore, we saw the lack of landowners' responsibilities in practice implementation as a challenge that negatively affected landowner engagement.

6. Institutional arrangements: Creating a multi-stakeholder project is favorable as it aggregates the funds and competencies available for a FLR project $[8,37]$. However, the role that each institution assumes may impose challenges on or favor the success of the project. For Water Producer/PCJ, the fact that there was no single local leading institution working with landowners and implementing practices was clearly a challenge that restricted participation and project progress. The sharing of implementation practices among many partners was also a challenge, because landowners were talking with different institutions, which they found confusing and disliked. Comments heard from landowners were sometimes negative because of the fact that an international NGO which they did not know of before the project was leading the process, and because of the direct participation of the state environmental agency, which is responsible for fines and punishments. Although these two institutions were crucial for project planning and functioning [24], the perception from landowners was that they would prefer to work with a local institution that is well-known to them. Finally, there was no direct participation of landowners in the decision-making processes of the project, and decisions were made only by project partners in regular meetings. Project partners noticed all of these issues, but it was still challenging to have local institutions leading field activities and prospecting landowners. There were no technical protocols established in the local institutions to coordinate these activities, and there were no local companies trained to implement FLR practices. To address these issues, in 2012, Terra Roxa, a non-profit organization employing local people, was hired to exclusively prospect landowners and to plan all aspects of the technical projects. We believe this was crucial for the increases in landowner participation and in the number of PES contracts observed in 2012 and 2013.

7. Land tenure issues: All of the landscapes were colonized centuries ago, during a time when documentation to prove land tenure was incomparable to that required currently. Thus, in many cases, absence of land tenure documents restricted landowner participation, as has been observed in other PES and FLR projects [38]. Collecting and processing the long list of land tenure and personal documents required for participation in the project took time. Additionally, project partners did not want to risk paying those living on the lands without a legal title, given that the funds for PES were public. This delay frequently created a time lag between the landowner's expression of interest and the implementation of FLR practices, which possibly negatively affected the willingness of fellow landowners to participate. Over time, the land tenure documentation required for participation was revised and simplified, but this was still a challenge up until the end of the project, given the characteristics of the region.

8. Proximity to the "Conservador das Águas" Project: The "Conservador das Águas" Project is a successful and well-known PES program for rural landowners in the municipality of Extrema-MG [19,26], which is just few kilometers away from Joanópolis and Nazaré Paulista. 
This was initially a positive factor for Water Producer/PCJ, because landowners in Joanópolis and Nazaré Paulista had heard positive feedback on a PES scheme in the region. However, this proximity also raised comparisons between the two projects, and lead to the expectation of landowners in Joanópolis and Nazaré Paulista that Water Producer/PCJ would be similar to the "Conservador das Águas" project. Although both projects were working in biophysically and socioeconomically similar landscapes, the projects were dissimilar in institutional arrangement, source of funds, strategies for elaboration of PES contracts, and practice implementation $[19,39]$ and, consequently, in the results that they achieved [14,26]. For example, the "Conservador das Águas" project was created, coordinated, and fully implemented by the municipal environmental secretary, while Water Producer/PCJ lacked leadership from local institutions. Although not fully explicable, the differences in outcomes between these two projects raise the question of how invisible and frequently neglected components of the landscapes, such as the social relationships between landowners and project partners, may be relevant for the overall implementation success of FLR projects.

9. Changes to environmental laws in Brazil: The project was active during a period when discussions over the Brazilian forest laws were occurring, which culminated in a change from the Forest Code to the Native Vegetation Protection Law of Brazil in 2012 [30]. This new federal law changed the amount of area in private rural properties that should be set aside for ecological restoration $[30,40]$. Clearly, this policy change negatively affected landowner participation in Water Producer/PCJ, given that they were not disposed to reserve areas for forest restoration in their properties until the new law was promulgated and the steps for its implementation by the Brazilian government were established (actually, this is still under discussion in São Paulo state).

\subsection{Technical Challenges for Implementation Practices and Progress}

1. Nature of areas designated for forest restoration: A practical challenge for the implementation and success of forest restoration practices in Water Producer/PCJ was the presence of many degraded riparian areas subject to flooding. Restoration of seasonally flooded tropical forests remains challenging [30,41]. There was high seedling mortality during flooding events [42], and there is still a lack of effective techniques to perform forest restoration in these areas. This is a general issue for tropical forest restoration, and thus it is not a problem specific to Water Producer/PCJ. However, these difficulties negatively affected the progress of forest restoration practices, and resulted in unsatisfactory results in some areas. Thus, it is worth considering these restrictions prior to defining the goals and targets for forest restoration in a FLR project.

2. Absence of a local forest restoration supply chain: Even though there are many large forest restoration projects and programs in the Brazilian Atlantic Forest [43,44], not all of its regions have a well-established forest restoration supply chain. Neither local tree seedling nurseries nor local institutions with the capacity to execute projects and implement forest conservation and restoration were present in the landscapes at the beginning of the project. This shortcoming was partially addressed by the project in 2012, when riparian forest restoration was initiated by a regional NGO (Appendix B) which hired and trained local people to work in the forest restoration chain. We believe this was an important step for the progress of the project practices, and that this should be carefully considered when planning PES or FLR projects for a specific region.

\subsection{Challenges in Making the Project Notable and Valuable}

1. Absence of local hydrological monitoring: As with most of the water-related PES projects implemented in Brazil [14,45] and other countries in Latin America [8,46], Water Producer/PCJ started without baseline hydrological monitoring. When projects lack baseline data, calibration and validation of complex ecohydrological models are needed to explore FLR effectiveness through the simulation of scenarios [23]. The lack of a local hydrological monitoring system for collecting data since the beginning of the project limits evidence of its effectiveness in reaching its 
goals. For instance, in 2013 and 2014, the Cantareira System experienced an extreme drought that resulted in a severe water-crisis in São Paulo state $[17,18]$. During this water crisis, a unique field investigation with hydrological monitoring was established at Cantareira's headwaters where PES projects had previously been set up [22]. Despite these 2013-2014 field campaigns addressing freshwater quantity and quality, they were not able to link the results to FLR practices because there was no previous hydrological monitoring data.

2. Complexity of hydrological monitoring to prove the effectiveness of FLR in terms of water conservation: During the 2013-2014 water crisis, several public and private institutions joined efforts to select Water Producer/PCJ sites for long-term hydrological monitoring. This multi-stakeholder plan for hydrologic monitoring assumed that, if available, data from the Water Producer/PCJ project would be a valuable example of how FLR practices and projects could alleviate local water shortage crises [21]. Despite its importance, implementing hydrological monitoring in FLR projects or in water-related PES schemes remains a challenge. First, whole catchments are not always the limit of water-related project sites, as observed in one of the landscapes in the Joanópolis municipality, where headwaters were outside of the area covered by the project (Figure 1). In addition, there is usually a dispersion of FLR practices in the landscape, and expected water quality and regularity of flow benefits are achieved at the local scale (i.e., at small nested catchments), which may not be observed through monitoring at the landscape level [47]. This was the case for Water Producer/PCJ. In these situations, monitoring has to be done at the micro-watersheds where FLR practices are being implemented. Finally, water yield is influenced by many factors, such as scale, climate variability and change, landowner management practices, changes in Brazilian forest law, and other factors not controlled by the project. Therefore, simulating land-use and forest cover scenarios for 1990, 2010, and 2035 has introduced uncertainty as to the effectiveness of Water Producer/PCJ in terms of increasing water yield at the landscape level [23].

3. Poor understanding of the length of time needed for positive changes: Some stakeholders and funding institutions of Water Producer/PCJ did not realize that many FLR actions take a long time to generate benefits at the landscape level. Forest restoration, for example, takes years to reestablish forest cover and biodiversity and to provide ecosystem services [48,49]. It is also true that PES are relatively new schemes, and consequently their results may take a longer time than expected to appear because there are many new situations and setbacks in their implementation. Although project partners recognized this, we highlight this should be better discussed prior to the project start, with the aim of establishing real goals and expectations among stakeholders.

\section{Conclusions}

As conclusion we list below the lessons learned and their implications for future PES schemes and FLR projects.

\subsection{Having Funds Is Not a Guarantee of Success for FLR Projects}

Water Producer/PCJ has showed us that having funds is not a guarantee of success in FLR projects. During the course of Water Producer/PCJ, less than $50 \%$ of the funds initially available for the planned activities were spent. Of course, funds are crucial for any FLR project, and the availability of regular funds is particularly essential for long-term project sustainability [37,50]. However, as mentioned above, many challenges can impose barriers to using these funds. For Water Producer/PCJ, we faced strong limitations in terms of fund-use flexibility, and reallocation of funds among supported activities was restricted because the model of contract signed with the funding agency (Brazilian federal bank) was limiting in this regard and because the agency managing the contract also had no experience of similar projects. Thus, we suggest that when planning similar projects (with similar funding sources), fundraisers should always bear this in mind when planning activities, sourcing funding institutions, and outlining funds usage. The project clearly demonstrated that water use charges are a potential 
source of funds for FLR projects. However, in this case study, it would have been better if we had proposed general and realistic (conservative) goals for the funding agency instead of detailing activities and creating specific goals for each FLR practice. Based on this, we have also learned that PES schemes for rural landowners that implement FLR practices are more complex than initially thought. Payment for ecosystem services is still a novelty for landowners, and this brings many challenges relating to their participation [19], as we exposed above. Furthermore, no size fits all—each region may require a specific approach to engage landowners, to fundraise, and to develop a successful project [8].

We also have learned that in PES schemes supporting implementation of FLR practices in rural landscapes, funds for PES to landowners is just one small component of a project budget. Thus, we recommend that those planning similar projects look beyond PES funds and obtain financial support for project communication, monitoring, and, particularly, for the implementation of FLR practices. Unless a project decides upon very high values for PES, the costs of implementation will be always much higher than those needed for PES payments to landowners.

\subsection{PES Schemes Are More Complex than Initially Thought, and PES Alone May Not Engage Landowners in a FLR Project}

Landowner participation was a great challenge for Water Producer/PCJ. From the 38 landowners that participated in the project, we believe that many would participate in a FLR project even without PES. This suggest that PES alone will not solve the problem of landowner participation, and that it may not be the major factor affecting landowner participation in FLR projects [19,39,51]. Feeling of ownership, past experiences, trust in the leading institution, and level of information given to landowners about the project may count for more than PES in landowners' decisions to participate or not. Thus, these aspects have to be carefully examined when planning PES or FLR projects in a given landscape.

We have learned that local institutions leading project implementation and prospection of landowners is crucial. When local institutions are not available or are not trained to lead projects, it is essential to capacitate a new local institution if necessary. Otherwise, long-term sustainability, which depends on local institutions leading the process, is unlikely to be achieved. This also applies to companies, NGOs, or people implementing FLR practices.

We found that, even when enrolled in the project, landowner engagement was generally low. Many factors may have contributed to this behavior. A major consideration is that landowners lacked a feeling of ownership because they did not participate in project decisions nor did they have a role in implementing any of the FLR practices. Landowner participation in project planning and decisions is essential; after all, projects are designed for them and have to be consistent with their expectations and needs [29,52]. This can also be a challenge, because conflicts frequently arise between landowners' interests (usually focused on productive and profitable activities) and the natural resource conservation goals that are demanded by project partners. We observed this conflict in Water Producer/PCJ, reinforcing that balancing landowners' expectations and ecological outcomes is still a major challenge for FLR projects. However, social acceptance, ownership, and trust of local organizations are major requirements for the improvement of similar projects in the future. Ways to achieve this involve recognizing and balancing local needs and the perceptions of all partners in project goals and functioning early on in the project.

When considering PES schemes in FLR projects, one alternative to increase landowner engagement is to consider larger and more frequent PES payments to landowners. These values should not be defined solely based on the opportunity costs of the most common productive land-uses in the landscape. They should also include part of the costs for implementation. Alternatively, landowners could be required to implement some of the FLR practices, such as fencing, planting trees, or adopting their own soil conservation techniques, to be eligible for the PES. This requirement may increase their engagement and personal investment in the project, especially for forest restoration practices, which 
tend to be less accepted by landowners because they are expensive practices that often require a change from a productive to a non-profitable conservation land-use.

\subsection{Acceptance Is Easier for Forest Conservation Practices Than It Is for Practices That Require Land-Use Change}

Acceptance and implementation are easier for forest conservation practices that require no land-use change than they are for forest restoration and soil conservation practices. A Brazilian Federal Law (n.11248, from 2006) prohibits the conversion of remaining Atlantic Forest fragments to agricultural areas, and there are restrictions in place to limit their use for economical exploitation of timber and non-timber products [30]. Thus, landowners view PES for forest conservation as a form of financial compensation in return for not using or cutting these forests. The same view does not apply when restoration practices require landowners to change their land-use, especially when non-profitable land-uses are proposed. Generally, practices that propose new land-uses are more expensive to implement than forest conservation practices. The benefits of forest conservation may not be the same as the benefits of restoration, and determining these benefits requires assessing the value of forest buffers through time, as well as quantifying the likelihood that remaining forest would be cleared or degraded in the absence of PES. However, based on the lessons we learned, we suggest that in landscapes where native forest is still being degraded or threatened, PES schemes should primarily target forest conservation. Within these landscapes, projects should focus on: (1) targeting private properties on marginal agricultural lands with a high probability of natural regeneration success or other measures of forest recovery success, where opportunity costs and costs for reestablishing forest are lower; and (2) targeting properties with remnant forest cover with high conservation value. In both cases, PES schemes would only be additional if current land uses are limiting natural forest regeneration potential or threating native forest fragments. For the second target, the lesson learned was used by the São Paulo State environmental agency in Brazil to implement a PES project paying landowners who converted their high conservation value forest fragments into private reserves (state resolution n.89, from 2013). Until now, this project has created 19 private reserves, protecting 3007 ha of high conservation value forests (reference-http: //fflorestal.sp.gov.br/pagina-inicial/rppn/projeto-de-pagamento-por-servicos-ambientais-psa/).

\subsection{Monitoring of the Ecosystem Services That Motivated the PES Scheme in FLR Projects Is Essential}

Monitoring of restored or conserved hectares is essential to evaluate whether or not goals and targets of the project are being achieved. However, in PES schemes and FLR projects, target outcomes cannot be monitored by only monitoring the hectares where practices have been implemented. Specific information collected should include early and periodical measures of livelihood indicators and satisfaction of participant landowners. We highlight the importance of collecting baseline data and monitoring as a way of identifying and addressing challenges for landowner participation early on in the project. These are indicators that can further encourage the achievement of project restoration and conservation goals. Moreover, it is essential to monitor the provision of the ecosystem services that motivated the project. Otherwise, a project may fail in both evaluating its overall success and in advertising its effectiveness to stakeholders and society. In the specific case of water-related ecosystem services, we highlight the need to consider watersheds as landscape limits whenever possible. Moreover, projects should have long-term hydrologic monitoring of quali-quantitative indicators. Ideally, at least in pilot projects, long-term monitoring should cover between 30 and 50 years, as this time span is needed to consolidate land-use and socio-economic changes. An important approach for both overall and hydrological monitoring is participatory monitoring, which involves stakeholders collecting and processing the data [53], and can increase landowner participation and long-term project sustainability. Some hydrological monitoring methods, especially long-term automatic monitoring, are complex and expensive, but a few low-cost methods could be utilized through the participatory monitoring. Some indicators related to the water ecosystem services can be easily determined by landowners as citizen gauges. For example, for water quantity, assuming that there is an updated rating curve (level versus flow discharge) for the restored watershed, the landowners could measure the water level daily. Then, 
the specialists could obtain the discharges by interpolation of the level into the rating curve. In parallel, the role of forests in the surface hydrology (water quality) can be assessed through adaptations of rapid evaluation protocols applied at the watershed scale [54,55].

Finally, although we evaluated a single case study in Brazil, many of the challenges and lessons learned described herein may be faced by FLR projects in other regions of the world. We advocate that taking these issues into consideration during project planning could help to avoid the same mistakes, and could improve the implementation of similar projects in the future.

Author Contributions: R.A.G.V., H.B. and D.T. structured and listed the lessons learned on the Water Producer PCJ. R.A.G.V. structured and wrote most of the manuscript and H.B. and D.T. add topics to it.

Funding: This research received no external funding.

Acknowledgments: We gratefully acknowledge Robin L. Chazdon for reviewing and commenting on early versions of the manuscript, Eduardo Mario Mendiondo for comments on the hydrological monitoring topics and all Water Producer/PCJ partners who manifested her or his opinion on the project when contacted. We also gratefully acknowledge the support of the Coordination for the Improvement of Higher Education Personnel (CAPES) for the post-doctoral scholarship to D.T. (CAPES/PNPD, Grant 2016-1314). This work was partly supported by the National Institute of Science and Technology for Climate Change Phase 2 under CNPq Grant 465501/2014-1, and FAPESP Grants 2014/50848-9 and the National Coordination for High Level Education and Training (CAPES) Grant 88887.136402/2017-00.

Conflicts of Interest: The authors declare no conflict of interest.

\section{Appendix A}

Interview held in Joanópolis-SP, Brazil on 04/16/2019, with a landowner that participated in the Water Producer/PCJ project:

The interview was conducted with the owner of the Bela Vista farm, which participated in the Water Producer/PCJ Project (nominated as "Intervention Catchment") and is recognized for the production of organic foods. The property of 363 ha has belonged to her family for four generations and is used for cattle ranching (approximately 300 animals) and production of seeds and organic foods. There are also three sites of older than 20 years old eucalyptus plantings. The landowner says there is a native forest on the property, but she does not know its area. He also says that there are many springs, but she does not know how many. In 2011, Water Producer/PCJ partners counted 14 springs in this property. The water used in the property for the development of its economic activities comes from a reservoir, supplied by waterbodies within the property.

When asked about water scarcity, she says that the amount of water has decreased greatly, emphasizing the year 2014, when a water crisis increased water scarcity in the Cantareira System. She says that in her childhood, she used to swim in the river near the property, but that today it is no longer possible, since the river is shallow and narrow. This indicates erosion and silting processes, as well as the water scarcity itself. Besides, she says that whenever there is a more intense precipitation, there is flooding in her property and surroundings. However, both scarcity and flooding did not affect her family business. When asked, she says she thinks that the shortage will worsen if no action is taken, and that she thinks that garbage, deforestation and other factors are related to these occurrences. She says she had never had problems with waterborne diseases, and complemented saying "the water here is very pure". Fifty years ago, the municipality of Joanópolis (SP) was supplied with water from her property, but because the population grown (currently, Joanópolis has 12 thousand inhabitants—http:/joanopolis.sp.gov.br/portal-turistico/), the municipal government found another source of water.

The farm does not use agrochemicals in its plantations and the owner says that the soil without pesticides is healthier and produces with greater efficiency. She has no problems with pests and that everything grows on the property. According to her, this is indicative of ecological balance in your property. The landowner is concerned on the rural exodus and says that people leave the farms for the city, but forget that the population living in cities needs food supplies from rural lands. 
When asked what could be done for avoiding suffer from hydrological and climatic extreme for the next generations, she reported education and awareness are needed, as well as the benefits of participating in river basin restoration projects such as the Water Producer/PCJ.

\section{Appendix B}

Table A1. Institutions participating in the Water Producer Project at the Piracicaba, Capivari, and Jundiai Watershed, Atlantic Forest, Brazil.

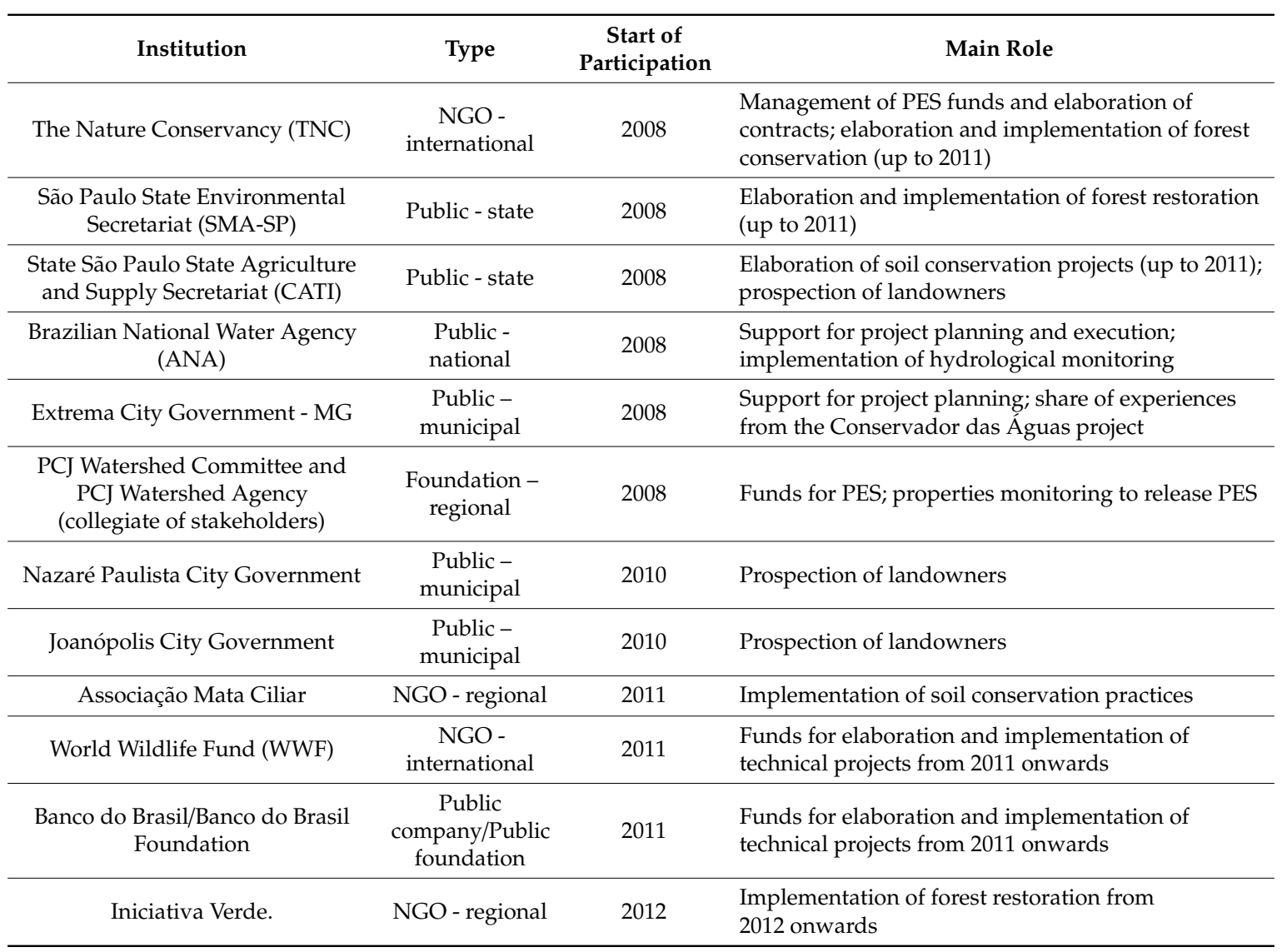

\section{Appendix C}

Table A2. Values for payment for ecosystem services (USD. ha-1. year-1) to landowners for forest conservation practices in the Water Producer Project at the Piracicaba, Capivari, and Jundiai Watershed, Atlantic Forest, Brazil. 1 USD = BRL 4 (November, 2019). APP: riparian areas of permanent protection according to the Brazilian native vegetation protection law.

\begin{tabular}{cccc}
\hline \multirow{2}{*}{ Forest Successional Status } & \multicolumn{2}{c}{ Amount of the APP with Forest or Accepted for Restoration by the Project } \\
\cline { 2 - 4 } & $\mathbf{1 5 - 3 0 \%}$ & $\mathbf{3 1 - 6 0 \%}$ & $\mathbf{6 0}$ \\
\hline Early successional forest & 6.25 & 12.5 & 18.75 \\
Medium to advanced & 10.5 & 20.75 & 31.25 \\
$\quad$ successional forest & & & \\
\hline
\end{tabular}


Table A3. Values for payment for ecosystem services to landowners for soil conservation practices in the Water Producer Project at the PCJ Watershed, Atlantic Forest, Brazil. 1 USD = R\$ 4 (November, 2019).

\begin{tabular}{cc}
\hline Soil Erosion Abatement for the Practice & Value (USD. ha ${ }^{\mathbf{1}}$. Year ${ }^{\mathbf{- 1}}$ ) \\
\hline $25-50 \%$ & 6.25 \\
$51-75 \%$ & 12.5 \\
$>75 \%$ & 18.75 \\
\hline
\end{tabular}

\section{References}

1. McDonald, T.; Gann, G.; Jonson, J.; Dixon, K. International Standards for the Practice of Ecological Restoration-Including Principles and Key Concepts; Society for Ecological Restoration: Washington, DC, USA, 2016.

2. Dudley, N.; Mansourian, S.; Vallauri, D. Forest Landscape Restoration in Context. In Forest Restoration in Landscapes: Beyond Planting Trees; Mansourian, S., Vallauri, D., Eds.; Springer: New York, NY, USA, 2005; pp. 3-7. [CrossRef]

3. Chazdon, R.L.; Brancalion, P.H.S.; Lamb, D.; Laestadius, L.; Calmon, M.; Kumar, C. A Policy-Driven Knowledge Agenda for Global Forest and Landscape Restoration. Conserv. Lett. 2017, 10, 125-132. [CrossRef]

4. Montagnini, F.; Finney, C. Payments for Environmental Services in Latin America as a Tool for Restoration and Rural Development. Ambio 2011, 40, 285-297. [CrossRef] [PubMed]

5. FAO. Global Mechanism of the UNCCD. Sustainable Financing for Forest and Landscape Restoration: Opportunities, Challenges and the Way Forward; FAO: Rome, Italy, 2015.

6. Pagiola, S.; von Glehn, H.C.; Taffarello, D. Brazil's Experience with Payments for Environmental Services; World Bank-Latin America and Caribbean Sustainable Development Department: Washington, DC, USA, 2013.

7. Leimona, B.; van Noordwijk, M.; de Groot, R.; Leemans, R. Fairly efficient, efficiently fair: Lessons from designing and testing payment schemes for ecosystem services in Asia. Ecosyst. Serv. 2015, 12, 16-28. [CrossRef]

8. Bremer, L.L.; Auerbach, D.A.; Goldstein, J.H.; Vogl, A.L.; Shemie, D.; Kroeger, T.; Nelson, J.L.; Benítez, S.P.; Calvache, A.; Guimarães, J.; et al. One size does not fit all: Natural infrastructure investments within the Latin American Water Funds Partnership. Ecosyst. Serv. 2016, 17, 217-236. [CrossRef]

9. Wuethrich, B. Reconstructing Brazil's Atlantic Rainforest. Science 2007, 315, 1070-1072. [CrossRef] [PubMed]

10. Joly, C.A.; Rodrigues, R.R.; Metzger, J.P.; Haddad, C.F.B.; Verdade, L.M.; Oliveira, M.C.; Bolzani, V.S. Biodiversity Conservation Research, Training, and Policy in São Paulo. Science 2010, 328, 1358-1359. [CrossRef] [PubMed]

11. Brancalion, P.H.S.; Viani, R.A.G.; Calmon, M.; Carrascosa, H.; Rodrigues, R.R. How to Organize a Large-Scale Ecological Restoration Program? The Framework Developed by the Atlantic Forest Restoration Pact in Brazil. J. Sustain. For. 2013, 32, 728-744. [CrossRef]

12. Myers, N.; Mittermeier, R.; Mittermeier, C.G.; Da Fonseca, G.; Kent, J. Biodiversity hotspots for conservation priorities. Nature 2000, 403, 853-858. [CrossRef]

13. Ribeiro, M.C.; Metzger, J.P.; Martensen, A.C.; Ponzoni, F.J.; Hirota, M.M. The Brazilian Atlantic Forest: How much is left, and how is the remaining forest distributed? Implications for conservation. Biol. Conserv. 2009, 142, 1141-1153. [CrossRef]

14. Taffarello, D.; Calijuri, M.D.C.; Viani, R.A.G.; Marengo, J.A.; Mendiondo, E.M. Hydrological services in the Atlantic Forest, Brazil: An ecosystem-based adaptation using ecohydrological monitoring. Clim. Serv. 2017, 8, 1-16. [CrossRef]

15. ANA—Agência Nacional de Águas. Manual Operativo do Programa Produtor de Água; ANA—Agência Nacional de Águas: Brasília, Brazil, 2012.

16. Programa Produtor de Água. Available online: https://www.ana.gov.br/programas-e-projetos/programaprodutor-de-agua/projetos2018 (accessed on 11 June 2019).

17. Nobre, C.A.; Marengo, J.A.; Seluchi, M.E.; Cuartas, L.A.; Alves, L.M. Some Characteristics and Impacts of the Drought and Water Crisis in Southeastern Brazil during 2014 and 2015. J. Water Resour. Prot. 2016, 8, $252-262$. [CrossRef] 
18. Escobar, H. Drought triggers alarms in Brazil's biggest metropolis. Science 2015, 347, 812. [CrossRef] [PubMed]

19. Richards, R.C.; Kennedy, C.J.; Lovejoy, T.E.; Brancalion, P.H.S. Considering farmer land-use decisions in efforts to 'scale up' Payments for Watershed Services. Ecosyst. Serv. 2017, 23, 238-247. [CrossRef]

20. Ruggiero, P.G.C.; Metzger, J.P.; Tambosi, L.R.; Nichols, E. Payment for ecosystem services programs in the Brazilian Atlantic Forest: Effective but not enough. Land Use Policy 2019, 82, 283-891. [CrossRef]

21. Taffarello, D.; Guimarães, J.; Lombardi, R.K.S.; Calijuri, M.C.; Mendiondo, E.M. Hydrologic Monitoring Plan of the Brazilian Water Producer/PCJ Project. J. Environ. Prot. 2016, 7, 1956-1970. [CrossRef]

22. Taffarello, D.; Mohor, G.S.; Calijuri, M.C.; Mendiondo, E.M. Field investigations of the 2013/2014 drought: quali-quantitative freshwater monitoring at the headwaters of Cantareira System, Brazil. Water Int. 2016, 41, 776-800. [CrossRef]

23. Taffarello, D.; Srinivasan, R.; Mohor, G.S.; Guimarães, J.L.B.; Calijuri, M.C.; Mendiondo, E.M. Modeling freshwater quality scenarios with ecosystem-based adaptation in the headwaters of the Cantareira system, Brazil. Hydrol. Earth Syst. Sci. 2018, 22, 4699-4723. [CrossRef]

24. Viani, R.A.G.; Bracale, H. Produtor de Água no PCJ_Pagamento por Serviços Ambientais lições Aprendidas e Próximos Passos; The Nature Conservancy: São Paulo, Brasil, 2015.

25. Fisch, G.; Santos, T.A.; Silva, R.C. Water security in the Vale do Paraiba's basin: Future scenarios. Rev. Ambient Água 2017, 12, 881-887. [CrossRef]

26. Richards, R.C.; Rerolle, J.; Aronson, J.; Pereira, P.H.; Gonçalves, H.; Brancalion, P.H.S. Governing a pioneer program on payment for watershed services: Stakeholder involvement, legal frameworks and early lessons from the Atlantic forest of Brazil. Ecosyst. Serv. 2015, 16, 23-32. [CrossRef]

27. Viani, R.A.G.; Braga, D.P.P.; Ribeiro, M.C.; Pereira, P.H.; Brancalion, P.H.S. Synergism Between Payments for Water-Related Ecosystem Services, Ecological Restoration, and Landscape Connectivity Within the Atlantic Forest Hotspot. Trop. Conserv. Sci. 2018, 11, 1-9. [CrossRef]

28. Aqui tem Mata? Available online: https://aquitemmata.org.br/\#/ (accessed on 10 May 2019).

29. Tabarelli, M.; Pinto, L.P.; Silva, J.M.C.; Hirota, M.; Bedê, L. Challenges and Opportunities for Biodiversity Conservation in the Brazilian Atlantic Forest. Conserv. Biol. 2005, 19, 695-700. [CrossRef]

30. Brancalion, P.H.S.; Garcia, L.C.; Loyola, R.; Rodrigues, R.R.; Pillar, V.D.; Lewinsohn, T.M. Análise crítica da Lei de Proteção da Vegetação Nativa (2012), que substituiu o antigo Código Florestal: Atualizações e ações em curso. Nat. Conserv. 2016, 14, 1-16. [CrossRef]

31. Terra Mater. Serviços de Monitoramento Socioeconômico e de Percepção Ambiental em Microbacias Piloto-Projeto de Pagamento de Serviços Ambientais; Terra Mater: Piracicaba, Brazil, 2009.

32. Banks-Leite, C.; Pardini, R.; Tambosi, L.R.; Pearse, W.D.; Bueno, A.A.; Bruscagin, R.T.; Condez, T.H.; Dixo, M.; Igari, A.T.; Martensen, A.C.; et al. Using ecological thresholds to evaluate the costs and benefits of set-asides in a biodiversity hotspot. Science 2014, 345, 1041-1045. [CrossRef] [PubMed]

33. Inlfation.eu-Historic Inflation Brazil—CPI Inflation. Available online: https:/www.inflation.eu/inflationrates/brazil/historic-inflation/cpi-inflation-brazil.aspx (accessed on 11 June 2019).

34. Schomers, S.; Matzdorf, B. Payments for ecosystem services: A review and comparison of developing and industrialized countries. Ecosyst. Serv. 2013, 6, 16-30. [CrossRef]

35. Benini, R.M.; Lenti, F.E.B.; Tymus, J.R.C.; Silva, A.P.M.; Isernhagen, I. Custos de restauração da Vegetação nativa no Brasil. In Economia da Restauração Florestal; Benini, R.M., Adeodato, S., Eds.; The Nature Conservancy: São Paulo, Brasil, 2017.

36. Garcia, L.C.; Santos, J.S.; Matsumoto, M.; Silva, T.S.F.; Padovezi, A.; Sparovek, G.; Hobbs, R.J. Restoration challenges and opportunities for increasing landscape connectivity under the new Brazilian forest act. Nat. Conserv. 2013, 11, 181-185. [CrossRef]

37. Costanza, R.; de Groot, R.; Braat, L.; Kubiszewski, I.; Fioramonti, L.; Sutton, P.; Farber, S.; Grasso, M. Twenty years of ecosystem services: How far have we come and how far do we still need to go? Ecosyst. Serv. 2017, 28, 1-16. [CrossRef]

38. McLain, R.; Lawry, S.; Guariguata, M.R.; Reed, J. Toward a tenure-responsive approach to forest landscape restoration: A proposed tenure diagnostic for assessing restoration opportunities. Land Use Policy 2018. [CrossRef] 
39. Zanella, M.A.; Schleyer, C.; Speelman, S. Why do farmers join Payments for Ecosystem Services (PES) schemes? An Assessment of PES water scheme participation in Brazil. Ecol. Econ. 2014, 105, $166-176$. [CrossRef]

40. Soares-Filho, B.; Rajão, R.; Macedo, M.; Carneiro, A.; Costa, W.; Coe, M.; Rodrigues, H.; Alencar, A. Cracking Brazil's Forest Code. Science 2014, 344, 363-364. [CrossRef]

41. Tundisi, J.G.; Tundisi, T.M. Integrating ecohydrology, water management, and watershed economy: Case studies from Brazil. Ecohydrol. Hydrobiol. 2016, 16, 83-91. [CrossRef]

42. Zalewski, M. Ecohydrology and Hydrologic Engineering: Regulation of Hydrology-Biota Interactions for Sustainability. J. Hydrol. Eng. 2014, 20, A4014012. [CrossRef]

43. Rodrigues, R.R.; Lima, R.A.F.; Gandolfi, S.; Nave, A.G. On the restoration of high diversity forests: 30 years of experience in the Brazilian Atlantic Forest. Biol. Conserv. 2009, 142, 1242-1251. [CrossRef]

44. Pinto, S.R.; Melo, F.; Tabarelli, M.; Padovesi, A.; Mesquita, C.A.; Scaramuzza, C.A.M.; Castro, P.; Carrascosa, H.; Calmon, M.; Rodrigues, R.; et al. Governing and delivering a biome-wide restoration initiative: The case of Atlantic Forest Restoration Pact in Brazil. Forests 2014, 5, 2212-2229. [CrossRef]

45. Sone, J.S.; Gesualdo, G.C.; Zamboni, P.A.P.; Vieira, N.O.M.; Mattos, T.S.; Carvalho, G.A.; Rodrigues, D.B.B.; Sobrinho, T.A.; Oliveira, P.T.S. Water provisioning improvement through payment for ecosystem services. Sci. Total Environ. 2019, 655, 1197-11206. [CrossRef]

46. Arriagada, R.; Villaseñor, A.; Rubiano, E.; Cotacachi, D.; Morrison, J. Analysing the impacts of PES programmes beyond economic rationale: Perceptions of ecosystem services provision associated to the Mexican case. Ecosyst. Serv. 2018, 29, 116-127. [CrossRef]

47. Mendiondo, E.M.; Tucci, C.E.M. Escalas hidrológicas. I: conceitos. Rev. Bras. Recur. Hídr. 1997, 2, $21-44$.

48. Suganuma, M.S.; Durigan, G. Indicators of restoration success in riparian tropical forests using multiple reference ecosystems. Restor. Ecol. 2015, 23, 238-251. [CrossRef]

49. Lozano-Baez, S.E.; Cooper, M.; Ferraz, S.B.; Rodrigues, R.R.; Castellini, M.; Di Prima, S. Recovery of Soil Hydraulic Properties for Assisted Passive and Active Restoration: Assessing Historical Land-use and Forest Structure. Water 2019, 11, 86. [CrossRef]

50. Naeem, S.; Ingram, J.C.; Varga, A.; Agardy, T.; Barten, P.; Bennett, G.; Bloomgarden, E.; Bremer, L.L.; Burkill, P.; Cattau, M.; et al. Get the science right when paying for nature's services. Science 2015, 347, 1206-1207. [CrossRef]

51. Muradian, R.; Arsel, M.; Pellegrini, L.; Adaman, F.; Aguilar, B.; Agarwal, B.; Corbera, E.; de Blas, D.E.; Farley, J.; Froger, G.; et al. Payments for ecosystem services and the fatal attraction of win-win solutions. Conserv. Lett. 2013, 6, 274-279. [CrossRef]

52. Brancalion, P.H.S.; Chazdon, R.L. Beyond hectares: four principles to guide reforestation in the context of tropical forest and landscape restoration. Restor. Ecol. 2017, 25, 491-496. [CrossRef]

53. Evans, K.; Guariguata, M.R.; Brancalion, P.H.S. Participatory monitoring to connect local and global priorities for forest restoration. Conserv. Biol. 2018, 32, 525-534. [CrossRef] [PubMed]

54. Hannaford, M.J.; Barbour, M.T.; Resh, V.H. Training Reduces Observer Variability in Visual-Based Assessments of Stream Habitat. J. N. Am. Benthol. Soc. 1997, 16, 853-860. [CrossRef]

55. Kalma, J.D.; Calder, I.R. Land Surface Processes in Large-Scale Hydrology; World Meteorological Organization (WMO): Geneva, Switzerland, 1994.

(C) 2019 by the authors. Licensee MDPI, Basel, Switzerland. This article is an open access article distributed under the terms and conditions of the Creative Commons Attribution (CC BY) license (http://creativecommons.org/licenses/by/4.0/). 